\title{
Analisis Derajat Kepatuhan Wajib Pajak (UKM) terhadap Tax Amnesty Setu Setyawan ${ }^{1}$
}

\author{
Fakultas Ekonomi dan Bisnis, Universitas Muhammadiyah Malang ${ }^{1}$
}

\begin{abstract}
Abstrak
Penelitian ini bertujuan untuk menganalisis derajat kepatuhan wajib pajak terhadap tax Amnesty. Kepatuhan wajib pajak diproxikan dengan kesadaran, pengetahuan peraturan perpajakan, persepsi atas efektivitas sistem perpajakan, dan kepercayaan kepada pemerintahan. Tujuan penelitian ini untuk membuktikan secara empiris sejauh mana derajat kepatuhan wajib pajak atas kebjiakan tax amnnesty yang diprogramkan oleh pemerintah. Obyek penelitian adalah wajib pajak orang pribadi pelaku UKM di Malang Raya. Data diperoleh dengan membagikan kuesioner kepada 96 pemilik UKM sebanyak 96 respoden. dengan teknik convenience sampling. Analisis data menggunakan regresi linier berganda, dan untuk menentukan hipotesis digunakan uji $\mathrm{F}$, dan uji t. Hasil analisis menunjukkan bahwa variabel kesadaran dengan nilai beta sebesar 0.289, pengetahuan peraturan perpajakan dengan nilai beta sebesar 0.320, dan Derajat kepercayaan kepercayaan kepada pemerintah nilai beta sebesar 0.392 , ketiga variabel tersebut berpengaruh positif dan signifikan terhadap tax amnesty pajak wajib pajak Pelaku UKM. Sedangkan pengetahuan peraturan perpajakan dengan nilai beta sebesar 0.176 berpengaruh negatif dan tidak signifikan terhadap tax amnesty.
\end{abstract}

Kata kunci: kepatuhan; wajib pajak; tax amnety

\section{Pendahuluan}

Kemajuan pembangunan infrastruktur serta perekonomian suatu negara dapat didukung dari kemauan masyarakatnya sebagai wajib pajak dengan untuk mengikuti program tax amnesty. Kemauan untuk mengikuti program tax amnesty (willingness to pay tax) dapat diartikan sebagai suatu nilai yang rela dikontribusikan oleh seseorang (ditetapkan dengan peraturan) yang digunakan untuk membiayai pengeluaran umum negara dengan tidak mendapat jasa timbal (kontraprestasi) secara langsung (Rantung dan Adi, 2009) hal tersebut sejalan dengan pengertian pajak menurut undang- undang no 36 tahun 2018 pasal 1 yang berbunyi "pajak adalah kontribusi wajib kepada negara yang terutang oleh orang pribadi atau badan yang bersifat memaksa berdasarkan undang- undang, dengan tidak mendapatkan imbalan secara langsung dan digunakan untuk keperluan negara bagi sebesar-besarnya kemakmuran rakyat.

Untuk meningkatkan pendapatan pada sektor pajak pemerintah sering malukan regulasi atau paket kebijakan ekonomi khususnya ber-kaitan dengan penerimaan sektor pajak salah satunya adalah tex amnesty. Penerapan kebijakan tax amnesty (pengampunan pajak) setelah pengesahan Undang-Undang (UU) Nomor 11 Tahun 2016 tentang Pengampunan Pajak. Pengampunan pajak diharapkan menghasilkan penerimaan pajak yang selama ini belum atau kurang bayar, disamping meningkatkan kepatuhan untuk mengikuti program tax amnesty karena makin efektifnya pengawasan, didukung semakin akuratnya informasi mengenai daftar kekayaan wajib pajak. Dengan kata lain kebijakan ini juga diharapkan dapat meningkatkan subyek pajak maupun obyek pajak. Subyek pajak dapat berupa kembalinya dana-dana yang berada di luar negeri, sedangkan dari sisi obyek pajak berupa penambahan jumlah wajib pajak.

Pemahaman wajib pajak akan peraturan perundang-undangan perpajakan sangat dibutuhkan, karena dengan pemahaman tersebut maka wajib pajak dapat menjelaskan secara benar tentang kewajiban yang harus dipenuhinya. Undang-undang tentang perpajakan dengan jelas mencantumkan kewajiban para wajib pajak dalam untuk mengikuti program tax amnestynya, jika tidak memenuhi kewajiban tersebut maka sanksi yang dikenakan sudah sangat jelas. Tetapi di lapangan ada kalanya seorang wajib pajak yang berskala besar dapat melakukan kesepakatan dengan oknum petugas pajak untuk melakukan pengurangan jumlah nominasi pajak wajib pajak tersebut. Pihak yang diuntungkan adalah wajib pajak dan oknum petugas pajak, sedangkan pihak yang paling dirugikan adalah pihak pemerintah. Semua ini bersumber dari kurangnya kesadaran akan perpajakan, baik dari pihak wajib pajak maupun dari petugas pajak.

\footnotetext{
${ }^{1}$ setyawansety@gmail.com
} 
Disisi lain persepsi wajib pajak atas efektivitas sistem perpajakan juga berpengaruh pada kemauan wajib pajak untuk untuk mengikuti program tax amnesty. DJP membuat sistem pendukung yang diharapkan dapat memudahkan wajib pajak dalam membayar dan melaporkan kewajiban pajaknya yaitu dengan adanya e-filling, e-SPT, e-NPWP, drop box dan e-banking. Sehingga dengan sistem baru tersebut diharapkan wajib pajak mempunyai persepsi yang baik tentang sistem-sistem yang dimiliki oleh DJP saat ini. Sebelum adanya pembaharuan sistem pengisian SPT dan pembayaran pajak melalui internet, wajib pajak harus datang ke KPP untuk melakukan semua proses. Pada saat ini dengan adanya e-filling, e-SPT, e-NPWP, drop box dan e-banking, diharapkan persepsi wajib pajak atas sistem perpajakan meningkat, karena semua sistem tersebut membuat wajib pajak dapat melakukan semua proses pajak tepat waktu dan dapat dilakukan dimana saja sehingga kemauan wajib pajak meningkat untuk untuk mengikuti program tax amnesty (Nugroho, 2012,Widayati 2010, Handayani 2012.).

Sejalan permasalah tersebut penelitian ini memfokuskan permasalahan analisis derajat kepatuhan wajib pajak Usaha Kecil Menengah (UKM) terhadap program tax amnesty dimana kapatuhan wajib pajak diproxsikan dengan Derajat kesadaran, pengetahuan peraturan perpajakan, persepsi atas efektivitas sistem perpajakan, dan kepercayaan kepada pemerintahan dan Hukum. Tujuan penelitian adalah untuk membuktikan secara empiris sejauh mana Derajat kesadaran wajib pajak atas kebjiakan tax amnnesty yang diprogramkan oleh pemerintah. Obyek penelitian adalah wajib pajak orang pribadi yang mempunyai UKM di Malang Raya

\section{Metodologi}

Penelitian ini menggunakan analisis regresi linear berganda untuk mengetahui pengaruh derajat kesadaran, pengetahuan dan pemahaman peraturan perpajakan, persepsi yang baik atas efektifitas sistem perpajakan, dan tingkat kepercayaan terhadap pemerintah dan hukum terhadap taxe amnesty wajib pajak orang pribadi pelaku UKM. Responden dalam penelitian ini berjumlah 96 orang

\section{Hasil dan Pembahasan}

\section{a. Hasil Uji Regresi Berganda}

Dari jawaban responden pemilik UKM telah dilakukan beberapa uji yaitu uji validitas data dan pengujian asumsi-asumsi klasik ini harus dilakukan untuk memenuhi penggunaan regresi linier berganda hasil uji variable derajat kepatuhan wajiab pajak terhadap tax amnesty sebagai berikut:

\section{Tabel 1}

Hasil Uji Regresi Berganda Coefficients $^{\mathrm{a}}$

\begin{tabular}{|c|c|c|c|c|c|}
\hline \multicolumn{6}{|l|}{ Coefficients $^{\mathrm{a}}$} \\
\hline \multirow[b]{2}{*}{ Model } & \multicolumn{2}{|c|}{$\begin{array}{l}\text { Unstandardize } \\
\text { Coefficients }\end{array}$} & \multirow{2}{*}{$\begin{array}{l}\text { Standard } \\
\text { Coeff } \\
\text { Beta }\end{array}$} & \multirow[b]{2}{*}{$\mathrm{t}$} & \multirow[b]{2}{*}{ Sig. } \\
\hline & B & $\begin{array}{l}\text { Std. } \\
\text { Error }\end{array}$ & & & \\
\hline (Constant) & 2.574 & 2.002 & & 1.286 & .202 \\
\hline Kesadaran & .289 & .111 & 231 & 2.605 & .011 \\
\hline \multirow{3}{*}{$\begin{array}{ll}1 & \begin{array}{l}\text { Pengetahua } \\
\mathrm{n}\end{array} \\
\text { Presepsi } \\
\text { keperayaan }\end{array}$} & .176 & .116 & .124 & 1.514 & .133 \\
\hline & .320 & .123 & 220 & 2.603 & .011 \\
\hline & .392 & .084 & 400 & 4.672 & .000 \\
\hline \multicolumn{6}{|c|}{ a. Dependent Variable: Y } \\
\hline
\end{tabular}

Berdasarkan pada Tabel 4.16 didapatkan persamaan regresi sebagai berikut: $\mathrm{Y}=2,574+0,289 \mathrm{X} 1+0.176 \mathrm{X} 2+0.320 \mathrm{X} 3+0.392 \mathrm{X} 4$.

Hasil persamaan regresi diatas, nilai konstanta sebesar 2.574 artinya kesadaran, pengetahuan dan pemahaman atas peraturan perpajakan, persepsi yang baik atas efektifitas sistem perpajakan, dan tingkat kepercayaan terhadap sistem pemerintahan dianggap konstan maka rata-rata kemauan untuk taxe amnesty WP pribadi pelaku UKM sebesar 2.574 .

Koefisien regresi variabel kesadaran sebesar 0.289 artinya apabila kesadaran taxe amnestymengalami peningkatan satu satuan, maka kemauan untuk taxe amnesty wajib pajak orang pribadi Pelaku UKM(Y) akan meningkat sebesar 0.289 satuan, dengan asumsi variabel independen lain nilainya tetap.

Koefisien regresi variabel pengetahuan dan pemahaman atas peraturan perpajakan sebesar 0.176 artinya apabila pengetahuan dan pemahaman atas peraturan perpajakan mengalami peningkatan satu satuan, maka 
kemauan untuk taxe amnesty wajib pajak orang pribadi pelaku UKM (Y) akan meningkat sebesar 0.176 satuan, dengan asumsi variabel independen lain nilainya tetap.

Koefisien regresi variabel persepsi yang baik atas efektifitas sistem perpajakan (PER) sebesar 0.320 artinya apabila persepsi yang baik atas efektifitas sistem perpajakan mengalami peningkatan satu satuan, maka kemauan untuk taxe amnesty wajib pajak orang pribadi pelaku UKM (Y) akan meningkat sebesar 0.320 satuan, dengan asumsi variabel independen lain nilainya tetap.

Koefisien regresi variabel tingkat kepercayaan terhadap sistem pemerintahan sebesar 0.392 artinya apabila tingkat kepercayaan terhadap Pemarintah dan hukum mengalami peningkatan satu satuan, maka kemauan untuk taxe amnesty wajib pajak orang pribadi pelaku usaha UKM (Y) akan mengalami peningkatan sebesar 0.392 satuan, dengan asumsi variabel independen lain nilainya tetap.

\section{b. Hasil Signifikan Simultan (Uji Statistik F)}

Uji statistik F bertujuan untuk mengetahui pengaruh secara bersama-sama atau simultan variabel independen terhadap variabel dependen atau terikat. Kriteria yang digunakan adalah apabila probabilitas > 0,05 maka Ho diterima, sebaliknya jika probabilitas $<0,05$ maka Ho ditolak

Tabel 2

Hasil Uji Statistik F

\begin{tabular}{lllllll} 
ANOVA $^{\mathbf{a}}$ & & & & \\
\hline Model & \multicolumn{2}{l}{$\begin{array}{l}\text { Sum } \\
\text { Squares }\end{array}$} & ofdf & \multicolumn{2}{l}{$\begin{array}{l}\text { Mean } \\
\text { Square }\end{array}$} & Sig. \\
\hline & Regression & 305.100 & 4 & 76.275 & 16.84 & $.000^{\mathrm{b}}$ \\
1 & $\begin{array}{l}\text { Residual } \\
\text { Total }\end{array}$ & 412.140 & 91 & 4.529 & & \\
& 717.240 & 95 & & & \\
\hline
\end{tabular}

a. Dependent Variable: Y

b. Predictors: (Constant),

Berdasarkan tabel diatas diketahui bahwa nilai signifikan sebesar 0,000 atau lebih kecil dari nilai probabilitas (p-value) $0,05(0,000<0,05)$ ini berarti bahwa variabel independen yaitu kesadaran membayar pajak, pengetahuan dan pemahaman atas peraturan perpajakan, persepsi yang baik atas efektifitas sistem perpajakan, dan tingkat kepercayaan terhadap sistem pemerintahan dan hukum mempunyai pengaruh yang signifikan secara bersama-sama (simultan) terhadap kemauan untuk taxe amnesty wajib pajak Pelaku UKM.

Hasil uji hipotesis menunjukkan bahwa kesadaran membayar pajak, pengetahuan dan pemahaman atas peraturan perpajakan, persepsi yang baik atas efektifitas sistem perpajakan, dan tingkat kepercayaan terhadap sistem pemerintahan dan hukum berpengaruh signifikan terhadap kemauan untuk taxe amnesty wajib pajak Pelaku UKM. Dengan demikian semakin tinggi kesadaran membayar pajak, pengetahuan dan pemahaman atas peraturan perpajakan, persepsi yang baik atas efektifitas sistem perpajakan, dan tingkat kepercayaan terhadap pemerintahan dan hukum, maka semakin tinggi pula tingkat kemauan untuk taxe amnesty wajib pajak orang pribadi Pelaku UKM.

\section{Kesimpulan}

Pengujian hipotesis yang dilakukan membuktikan bahwa: 1) kesadaran berpengaruh positif dan signifikan terhadap kemauan untuk taxe amnesty wajib pajak Pelaku UKM. Hal ini menunjukkan sikap wajib pajak tentang kesadaran terhadap perpajakan cukup baik. Artinya kesadaran wajib pajak untuk memenuhi kewajiban pajaknya secara berkala guna pembangunan negara, telah dilaksanakan dengan tanpa ada rasa dirugikan; 2) pengetahuan peraturan perpajakan berpengaruh negatif dan tidak signifikan terhadap kemauan untuk taxe amnesty wajib pajak Pelaku UKM. Hal ini menunjukkan bahwa tingkat pengetahuan dan pemahaman wajib pajak atas peraturan perpajakan dapat juga menurunkan kemauan untuk taxe amnesty wajib pajak Pelaku UKM; 3) pengujian hipotesis yang dilakukan membuktikan bahwa persepsi yang baik atas efektifitas sistem perpajakan berpengaruh positif dan signifikan terhadap kemauan untuk taxe amnesty wajib pajak Pelaku UKM. Adanya sistem perpajakan yang baru yakni sistem perpajakan yang berbasis online, sistem ini akan semakin mempermudah wajib pajak untuk melakukan pembayaran dan pelaporan pajaknya; 4) tingkat kepercayaan terhadap sistem pemerintahan dan hukum berpengaruh positif dan signifikan terhadap kemauan untuk taxe amnesty wajib pajak Pelaku UKM. Hal ini menunjukkan bahwa semakin wajib pajak memiliki tingkat kepercayaan terhadap sistem pemerintahan dan hukum maka akan meningkatkan kemauan wajib pajak untuk membayar pajak. 


\section{Referensi}

1. Basri \& Satriawan., dkk. 2012. Studi Kepatuhan Pajak: Faktor yang Mempengaruhinya (Kasus pada Wajib pajak Orang Pribadi yang terdaftar di KPP Pratama Tampan Pekanbaru). Banjarmasin. Makalah Simposium Nasional A20kuntansi XV.

Fikriningrum, Winda Kurnia. 2012. Analisis Faktor-Faktor yang Mempengaruhi Wajib Pajak Orang Pribadi dalam Memenuhi Kewajiban Membayar Pajak. skripsi (S1). Fakultas Ekonomi dan Bisnis. Universitas Diponegoro. (diunduh pada 16 November 2013).

Ghozali, Imam. 2011. Ekonometrika. Semarang: Universitas Diponegoro.

Handayani, Faturokhman dan Pratiwi. 2012. Faktor-Faktor Yang Mempengaruhi Kemauan Membayar Pajak Wajib Pajak Orang Pribadi Yang Melakukan Pekerjaan Bebas. Banjarmasin. Makalah Simposium Nasional Akuntansi XV.

Hardiningsih dan Yulianawati. 2011. Faktor-faktor yang Mempengaruhi Kemauan Membayar Pajak (The Factors That Influence The Willingness To Pay The Tax). Dinamika Keuangan dan Perbankan, Nov. 2011. (diunduh pada 16 November 2013).

James Alm, Jorge Martinez-Vazquez, and Benno Torgler. 2005. Russian Attitudes Toward Paying Taxes Before, During, And After The Transition. Journal of Public Economics. Rusia:27 www.yale.edu/leitner/.../taxmorale-russia.pdf (diunduh pada 16 November 2013).

Muljono, Djoko. 2008. Ketentuan Umum Perpajakan. Yogyakarta: Andi

Nugroho. 2012. Faktor-faktor Yang Mempengerahui Kemauan Untuk Membayar Pajak Dengan Kesadaran Membayar Pajak Sebagai Variabel Intervening (Studi Kasus Wajib Pajak Orang Pribadi Yang Melakukan Pekerjaan Bebas Yang Terdaftar Di KPP Pratama Semarang Tengah Satu). Semarang. Universitas Diponegoro. (diunduh pada 16 November 2013).

Permadi, Nasir, dan Anisma. 2013. Studi Kemauan Membayar Pajak pada Wajib Pajak Orang Pribadi yang Melakukan Pekerjaan Bebas (Kasus pada KPP Pratama Tampan Pekan baru). Jurnal: Universitas Riau. (diunduh pada 16 November 2013).

Priyatno, Duwi. 2009. SPSS 17. Yogyakarta: Andi.

Rantung dan Hari Adi. 2009. Dampak Program Sunset Policy Terhadap Faktor - Faktor yang Mempengaruhi Kemauan Membayar. Madura. Makalah Simposium Nasional Perpajakan II.

Resmi, Siti. 2009. Perpajakan: Teori dan Kasus. Jakarta: Salemba Empat

Sekaran, Uma. 2006. Metode Penelitian Bisnis. Jakarta: Salemba Empat.

Setyawati, Eka. 2013. Faktor-Faktor Yang Mempengaruhi Kemauan Untuk Membayar Pajak Wajib Pajak Orang Pribadi Yang Melakukan Pekerjaan Bebas. Skripsi (S1). Jurusan Akuntansi. Fakultas Ekonomi dan Bisnis. Universitas Islam Negeri Syarif Hidayatullah. (diunduh pada 16 November 2013).

Undang-undang Republik Indonesia Nomor 28 Tahun 2007 Tentang Perubahan Ketiga Atas Undangundang Nomor 6 Tahun 1983 Tentang Ketentuan Umum dan Tata Cara Perpajakan. (diunduh pada 16 November 2013).

Undang-undang Republik Indonesia Nomor 36 Tahun 2008 Tentang Pajak Penghasilan. (diunduh pada 16 November 2013).

Undang-undang Republik Indonesia Nomor 46 Tahun 2013 Tentang Pajak Penghasilan Atas penghasilan dari usaha yang diterima atau diperoleh wajib pajak yang memiliki peredaran bruto tertentu. (diunduh pada 16 November 2013).

Utami, Rizki, Andi, dan Norida. 2012. Pengaruh Faktor-faktor Eksternal Terhadap Tingkat Kepatuhan Wajib Pajak Di Lingkungan Kantor Pelayan Pajak Pratama Serang. Banjarmasin. Makalah Simposium Nasional Akuntansi XV.

Waluyo. 2010. Perpajakan Indonesia. Jakarta: Salemba Empat.

Widayati dan Nurlis. 2010. Faktor-Faktor Yang Mempengaruhi Kemauan Untuk Membayar Pajak Wajib Pajak Orang Pribadi Yang Melakukan Pekerjaan Bebas (Studi Kasus Pada Kpp Pratama Gambir Tiga. Purwokerto. Makalah Simposium Nasional Akuntansi XIII.

Widodo, Widi dan Dedy Djefris. 2008. Tax Payer's Rights. Bandung: Alfabeta. 